\title{
COOPERATION BETWEEN \\ UNIVERSITIES AND CORPORATIONS
}

\author{
Rusk Masih \\ The University of Connecticut, \\ Avery Point Campus, Groton \\ Email r masih@yahoo.com
}

\begin{abstract}
This paper treats the role that can be played by both the universities and the industry together in shaping continuous engineering education, nationally and internationally. It recommends forming a joint committee from the industry and academia to define the plan to enhance the cooperation between the universities and corporations, and the execution of such plan. It also treats the interest of each party and how they could be cast to their joint benefit. The paper also recognizes that the ties between the academia and the industry in Europe and Japan are stronger than that which exists in USA. Furthermore, it recommends how to improve such ties for the benefit of all parties.
\end{abstract}

\section{What has been done so far?}

There has been a lot of talk about continuous engineering education in USA, however there is very little planning and execution in this field. In comparison to Europe and Japan US appears to be lagging quite behind them in this field. This author has published several papers, pointing out such slacks, and recommended methods to treat, Masih ${ }^{1,2,3}$

\section{What needs to be done to improve the present situation?}

There has to be a committee formed from knowledgeable entrusted people in both the industry and the academia. Such committee should address the proper issues. It should set up the agenda for the cooperation between the industry and academia, and draws a practical plan to enhance such cooperation. The committee should have a budget subscribed by the industry and the academia. The committee should study the need of the industry for research and the academia for research funding. Determine the capability of different industries to subscribe to such effort financially. It should also study the need of the academia for funding and its ability to conduct the research needed by the industry. Part of such funding should be allocated by the committee to encourage starting research at institutes, which do not have history of getting funded to encourage them to do such research. The other part of the funds should be allocated in a competitive way to the researching institutes.

"Proceedings of the 2005 American Society for Engineering Education Annual Conference \&Exposition copyright (C) 2005, American Society for Engineering Education" 


\section{Protecting the interest of all parties}

Needless to say, that each party has its own interest to protect. The industry does not want to waste its financial resources unless it will secure that there will be a return on its investment in research. Same way the academic institutions, they do not want to do research for nothing, because they need the money to continue their mission of research and education of the new generation. Accordingly the committee should establish guidelines for how the money is obtained and spent and how the research is conducted and carried on to protect the interest of all the parties.

\section{How to improve the quality of the practicing engineers}

Continuous engineering education is an important issue, not only for the industry, because it improves the quality of work done by the engineers, but also is important for the practicing engineers, because it shows them the continuous dynamic change in their own field of specialization and makes them more qualified to do their work up to the latest state of the art in their field of specialization. How to achieve a successful continuous engineering education is another story. It could take different forms in the engineers' practical professional life. One way to do it is conducting educational seminars, either in their offices or in the universities' classrooms. Conducting the seminars in the offices is much better way, not only because the approach is more practical, but also because it can orient the lectures in such a way to address the problems faced by that industry and its engineers. Another way to do it is by distant learning, where the lecturer use a video conference hooked to many sites, with interactive capability so that the listeners can interact with the lecturer, although this method is not that efficient because the listeners do not feel that they can interact one on one with the lecturer directly, nevertheless this method has its advantages, specifically the economic approach where one lecturer can reach several groups of people, in different locations at the same time. Another point related to this subject is what kind of quality the lecturer should have to qualify him for the task? The answer is the lecturer should have the practical experience in the subject besides the theoretical knowledge and competence. Having practical experience is extremely important, because most of the listeners will ask questions related to their own work, for which they want qualified answers.

Another aspect of improving the quality of practicing engineers is to give them an incentive to give them the sense of achievement, by crediting the valid experience of their work towards a degree. Such practice is widely used in Europe in a successful manner. In many European countries they follow this practice by forming a directive committee from university professors and experienced people in the industry to guide the practicing engineers who are in a continuous engineering education program and evaluate the engineer's experience in a specific field, then decide whether to credit him for such experience some credits towards the diploma.

"Proceedings of the 2005 American Society for Engineering Education Annual Conference \&Exposition copyright (C) 2005, American Society for Engineering Education” 


\section{Strengthening the ties between the industry and academia}

There are many ways to strengthen the ties between the industry and academia. One of them is holding seminars and conferences, dealing with the industry problems would make the industry more interested in what the academic institutions are doing, because they will realize that such conferences and seminars will help to improve the quality and professional understanding of their engineers. Unfortunately most of such conferences and seminars are dedicated to academic topics and abstract theories, which do not interest the industry very much.

Another way of strengthening such relationship is by forming joint committees, whose task is to study and find out how to make the academic research better serve the goals of the industry and how to make the industry understand the problems of the academic community and help it not only by giving it research grants but also a valid advise as to inform the academic community of the future trend in the industry to gear itself in its research and educational effort to such trends and goals.

\section{Forging stronger international ties between the organizations}

Why is it needed to forge stronger ties between the engineering organizations all over the world? Every organization has its own experience and rules of profession, which could be beneficial to other organization and could be copied by the sisters' organizations in other countries. Furthermore, such an overall umbrella organization could be helpful in taking collective actions to further the goals of the organizations in general. It can forge an exchange between the organizations in different countries to educate those organizations and make them aware of the conditions and experience of other countries. There is no doubt that experiencing success in one country is an invitation to other countries to follow the path of success.

\section{Narrowing the gaps between such organizations}

Studying the bylaws and policies of such organizations in different countries, point out to big difference in their rules and goals to be achieved. In some cases they are quite divergent from each other goals. For example when the European Union (EU) was formed, the union organization related to engineering was given the task of unifying engineering education and practice. It was faced with a monumental task of getting engineering education and practice unified. Some of those organization, such as the French engineering organization called FIANI by its abbreviated name, ran totally opposite policy and goals to what the EU was trying to achieve in unifying the engineering education and engineering profession. 


\section{Bibliography}

1- Masih, R.Y. Preparing the engineering education and profession for next century. Presented at the $5^{\text {th }}$ world conference on continuing engineering education in Helsinki, Finland, June 2-5, 1992 proceedings Vol. I PP 339-344.

2- Masih, R. Y. A further cooperative in engineering education. ASEE, New England Section conference, April 1996, PP 12.

3- Masih, R. Y. Corporate attitude towards academia need to be changed. IACEE $8^{\text {th }}$ world conference on continuing engineering education, May 2001, Toronto. PP 459-461.

\section{Biography}

Rusk Masih is associate Professor of engineering at The University of Connecticut. Before joining the academic community he worked in the industry for twenty years as senior design engineer, project engineer and project manager. After joining the university, he published more than seventy papers in the professional journals and conference proceedings, in the field of lift slab structures stability, geotechnical engineering and engineering education.

"Proceedings of the 2005 American Society for Engineering Education Annual Conference \&Exposition copyright (C) 2005, American Society for Engineering Education" 